\title{
KECERDASAN SPIRITUAL DAN PRESTASI HASIL BELAJAR SISWA (Studi Kasus di SMA Negeri 1 Godean)
}

\author{
Sri Handayani \\ Program Pasca Sarjana \\ Universitas Muhammadiyah Yogyakarta \\ E-mail: hsri35@gmail.com
}

\begin{abstract}
Abstrak
Penelitian ini bertujuan untuk: 1) mengetahui mengetahui kecerdasan spiritual siswa. 2) mengetahui prestasi hasil belajar siswa. 3) mengetahui keterkaitan kecerdasan spiritual siswa dan prestasi hasil belajar siswa. Pendekatan yang digunakan adalah metode pendekatan deskriptif kualitatif. Lokasi penelitian ini bertempat di SMA Negeri 1 Godean Kabupaten Sleman. Hasil penelitian ini menujukkan bahwa 1) kecerdasan spiritual siswa secara garis besar tergolong baik, 2) bahwa rata-rata motivasi belajar siswa SMA Negeri 1 Godean termasuk kategori Baik $(79,44 \%)$, 3) tingkat keterkaitan antara kecerdasan spiritual terhadap motivasi belajar siswa sanga baik.
\end{abstract}

Kata kunci: kecerdasan spiritual, prestasi hasil belajar, SMA Negeri 1 Godean

\footnotetext{
Abstract

This study aims to: 1) find out knowing students' spiritual intelligence. 2) knowing the achievement of student learning outcomes. 3) knowing the relevance of students' spiritual intelligence and student learning achievement. The approach used is a qualitative descriptive approach method. The location of this study took place at Godean 1 Public High School, Sleman Regency. The results of this study show that 1) the spiritual intelligence of students is broadly classified as good, 2) that the average learning motivation of Godean 1 Public High School students is in the category of Good (79.44\%), 3) the level of relationship between spiritual intelligence and student motivation very good.

Keywords:spiritual intelligence, learning achievement, Godean 1 Public High School
}

\section{Info Artikel}

Diterima Maret 2019, disetujui April 2019, diterbitkan Juni 2019 


\section{PENDAHULUAN}

Dewasa ini kemajuan di bidang ilmu pengetahuan dan teknologi demikian pesatnya. Sebagai konsekuensi logis, kita harus menyiapkan sumber daya manusia yang berkualitas, hal ini bukan berarti manusia yang hanya menguasai IPTEK (Ilmu pengetahuan dan teknologi) semata, melainkan harus pula memiliki IMTAQ (Iman dan taqwa). Dengan demikian, bangsa Indonesia senantiasa selain mampu mengikuti perkembangan di bidang ilmu pengetahuan dan teknologi, juga diharapkan mampu mengantisipasi pengaruh dari luar yang dapat merusak atau mengancam tatanan hidup, ideologi, kepribadian dan budaya bangsa.

Dengan demikian pentingnya menanamkan kecerdasan spiritual sebagai acuan dari agama dapat mempermudah siswa dalam memahami makna nilai dalam kehidupan ini. Seperti kemampuan bersikap, siswa yang memiliki kemampuan ini dapat melepaskan diri dari pengaruh budaya buruk masyarakat modern. Sebagaimana yang dikatakan oleh Danah Zohar dan Ian Marsall, bahwa jika manusia memiliki kecerdasan spiritual yang rendah, maka manusia tersebut akan berada dalam budaya spiritual yang rendah juga. Hal tersebut ditandai dengan sikap materialisme, egoisme diri yang sempit, kehilangan agama dan komitmen yang rendah. Walaupun kecerdasan spiritual berasaskan agama Islam, ini tidak berarti kecerdasan spiritual hanya ditunjukkan secara eksklusif untuk individu Islam saja, tapi untuk semua manusia tanpa melihat latar belakang agama atau bangsa. Oleh karena itu, sebagai manusia harus dididik untuk mempunyai beberapa kecerdasan dalam dirinya agar tidak tumbuh menjadi siswa yang tidak bertanggung jawab.

Hal ini menunjukkan betapa pentingnya nilai-nilai spiritual ditanamkan dalam diri siswa sejak dini. Jadi upaya menanamkan nilai spiritual dilakukan dalam rangka mengubah sikap dan tata laku siswa dalam rangka mengembangkan kualitas tentang pemahaman dan nilai-nilai yang buruk dan baik melalui upaya pengajaran dan pelatihan yang pelaksanaannya berkesinambungan sehingga siswa tumbuh menjadi yang berahklak, bermoral, beretika dan berbudi pekerti.

\section{PENGERTIAN KECERDASAN SPIRITUAL}

Kecerdasan memiliki arti yang beragam, namun membicarakan kecerdasan seolah-olah hanya berkaitan dengan kepandaian, kepintaran dan kesempurnaan akal. 
Sesungguhnya kecerdasan memiliki arti yang luas, yakni perbuatan yang disertai dengan pemahaman atau pengertian. David C. Edward mengartikan kecerdasan sebagai 'a general capacity of behave in an adapTabel and accepTabel manner'. Jadi, dapat disimpulkan bahwa kecerdasan adalah kemampuan yang dimiliki seseorang dalam memahami lingkungan atau alam sekitar serta berpikir rasional guna menghadapi tantangan serta dapat memecahkan berbagai masalah yang dihadapi.

Menurut Danah Zohar dan Ian Marshall kecerdasan spiritual (SQ) adalah kecerdasan untuk menghadapi dan memecahkan persoalan makna dan nilai yaitu kecerdasan untuk menempatkan perilaku dan hidup seseorang dalam konteks makna yang lebih luas dan kaya. Kecerdasan untuk menilai bahwa tindakan atau jalan hidup seseorang lebih bermakna dibandingkan dengan yang lain. Kecerdasan spiritual berupa landasan yang diperlukan untuk memfungsikan IQ dan EQ secara efektif.

Di sisi lain, kecerdasan spiritual seseorang mampu menyatukan hal-hal yang bersifat intrapersonal dan interpersonal, serta menjembatani kesenjangan antara diri dan orang lain. Kecerdasan spiritual merupakan kecerdasan yang paling tinggi baik secara langsung maupun tidak langsung. Kecerdasan spiritual juga berhubungan dengan kemampuan manusia mentransendensikan diri. Transendensi adalah sesuatu yang membawa manusia 'mengatasi' (beyond) masa kini, rasa duka bahkan mengatasi diri kita pada saat ini. Ia membawa manusia melampaui batas-batas pengetahuan dan pengalaman serta menempatkan pengetahuan dan pengalaman ke dalam konteks yang lebih luas.

Dari penjelasan di atas, dapat dipahami bahwa spiritualitas merangkum sisi-sisi kehidupan rohaniah dalam dimensi yang cukup luas, sehingga secara garis besar spiritualitas merupakan kehidupan rohani (spiritual) dan perwujudannya dalam cara berpikir, merasa, berdoa dan berkarya. Spiritualitas bukan agama, namun tidak dapat dilepaskan dari nilai-nilai keagamaan, karena ada titik singgung antara spiritualitas dengan agama.

\section{CIRI-CIRI KECERDASAN SPIRITUAL}

Seseorang yang memiliki kecerdasan spiritual mempunyai peranan penting dalam pembentukan kepribadian seseorang. Adapun indikator atau ciri-ciri orang yang memiliki kecerdasan spiritual antara lain: 
a. Merasakan kehadiran Allah. Orang yang bertanggung jawab dan cerdas secara ruhaniah, merasakan kehadiran Allah di mana saja berada. Seseorang meyakini bahwa salah satu produk keyakinannya beragama antara lain melahirkan kecerdasan moral spiritual yang menumbuhkan perasaan yang sangat mendalam, bahwa dirinya senantiasa berada dalam pengawasan Allah.

b. Memiliki Prinsip Hidup yang Jelas. Mereka yang cerdas secara spiritual, sangat menyadari bahwa hidup yang dijalaninya bukanlah kebetulan tetapi sebuah kesengajaan yang harus dilaksanakan dengan penuh rasa tanggung jawab (takwa). Bagi seseorang yang ingin mempertajam kecerdasan spiritualnya, menetapkan visinya melampui daerah duniawi sehingga menjadikan qalbunya sebagai suara hati yang selalu didengar.

c. Selalu Berdzikir dan Berdoa kepada Allah. Yang dimaksud dengan berdzikir adalah merasakan keagungan Allah dalam semua kondisi. Dzikir tersebut bisa berupa dzikir pikiran, hati, lisan, atau perbuatan. Dzikir perbuatan yang dimaksud di sini mencakup tilawah, ibadah dan keilmuan.

d. Sabar. Sabar bisa dipahami sebagai sebuah harapan kuat untuk menggapai cita-cita atau harapan, sehingga orang yang putus asa berarti orang yang kehilangan harapan atau terputusnya cita-cita. Dalam kandungan kualitas sabar, terdapat sikap yang istiqamah. Sabar berarti tidak bergeser dari jalan yang mereka tempuh.

e. Cenderung Pada Kebaikan. Orang-orang yang bertakwa (bertanggung jawab) adalah tipe manusia yang selalu cenderung kepada kebaikan dan kebenaran. Orang yang bertakwa atau bertanggung jawab berarti orang tersebut berupaya sekuat tenaga melaksanakan kewajiban (amanah) sedemikian rupa sehingga menghasilkan hasil kerja yang terbaik.

Berdasarkan penjelasan mengenai kecerdasan spiritual di atas, dapat disimpulkan sebagai indicator instrument penelitian, yaitu:

Tabel 1.

Indikator Kecerdasan Spiritual

\begin{tabular}{|c|c|}
\hline Indikator & Instrumen \\
\hline \multirow{3}{*}{$\begin{array}{l}\text { a. Merasakan } \\
\text { kehadiran Allah }\end{array}$} & a. Keyakinan adanya Allah \\
\hline & b. Shalat wajib \\
\hline & c. Merasa diawasi Allah \\
\hline
\end{tabular}




\begin{tabular}{|c|c|c|}
\hline \multirow{3}{*}{\multicolumn{2}{|c|}{$\begin{array}{l}\text { b. Selalu berdzikir } \\
\text { dan berdoa } \\
\text { kepada Allah }\end{array}$}} & a. Rajin Berdoa \\
\hline & & b. Kebiasaan membaca al-Qur'an \\
\hline & & c. Mendapatkan pertolongan Allah \\
\hline & \multirow{2}{*}{$\begin{array}{l}\text { Cenderung } \\
\text { kapada kebaikan }\end{array}$} & a. Bergaul sesuai etika \\
\hline & & b. Toleransi antarumat beragama \\
\hline \multirow{3}{*}{\multicolumn{2}{|c|}{ c. Sabar }} & a. Mudah memaafkan kesalahan \\
\hline & & b. Suka membantu orang lain \\
\hline & & c. Memperlakukan orang dengan baik \\
\hline
\end{tabular}

\section{PENGERTIAN MOTIVASI BELAJAR}

Sedangkan motivasi belajar menurut Hamzah B. Uno adalah dorongan internal dan eksternal pada siswa yang sedang belajar untuk mengadakan tingkah laku, pada umumnya dengan berupa indikator atau unsur-unsur yang mendukung. Indikatorindikator tersebut, antara lain adanya hasrat dan keinginan, dorongan dan kebutuhan dalam belajar, harapan dan cita-cita masa depan, penghargaan dalam belajar dan lingkungan belajar yang kondusif. Secara konseptual, motivasi belajar dapat diartikan sebagai sebuah dorongan yang muncul dalam diri seorang siswa secara sadar maupun tidak dalam suatu kegiatan belajar secara terus menerus untuk mencapai tujuan yang ingin dicapai sehingga terjadi perubahan tingkah laku.

Bophy mendefinisikan motivasi belajar adalah sebagai "a general state and a situation specific state". Sebagai 'a general state', motivasi belajar adalah suatu watak yang permanen yang mendorong seseorang untuk menguasai pengetahuan dan ketrampilan dalam suatu kegiatan belajar. Sedangkan sebagai 'a situation-specific state', motivasi belajar muncul karena keterlibatan individu dalam suatu kegiatan tertentu diarahkan oleh tujuan memperoleh pengetahuan atau menguasai keterampilan yang diajarkan. Menurut Afifudin, bahwa motivasi belajar adalah keseluruhan daya penggerak di dalam diri anak yang mampu menimbulkan kesemangatan/kegairahan belajar. Samidjo Mardiani memberikan definisi motivasi belajar adalah berbagai usaha yang dilakukan oleh seseorang dalam proses perkembangannya yang meliputi maksud tekat, hasrat, kemauan, kehendak, cita-cita dan sebagainya untuk mencapai tujuan. Kemudian Mulyadi, menyatakan bahwa definisi atau pengertian motivasi belajar adalah membangkitkan dan memberikan arah dorongan yang menyebabkan individu melakukan perbuatan belajar. Menurut Endang, motivasi belajar adalah sesuatu yang mendorong, menggerakkan dan mengarahkan siswa dalam belajar. 


\section{CIRI-CIRI MOTIVASI BELAJAR}

Menurut Sardiman ada beberapa ciri-ciri tentang motivasi antara lain adalah tekun menghadapi tugas, ulet dalam menghadapi kesulitan, menunjukkan minat dalam bermacam-macam masalah, lebih senang bekerja mandiri, cepat bosen dengan tugastugasyang rutinitas. Motivasi berfungsi untuk mendorong manusia berbuat, menentukan arah perbuatan, untuk mencapai tujuan dan menyeleksi perbuatan yakni mana yang akan dikerjakan. Menurut Harter terdapat tiga hal yang mempengaruhi motivasi berprestasi dalam kaitannya dengan kegiatan belajar di sekolah:

a. Kompetensi yang dirasakan oleh individu. Hal ini dipengaruhi oleh persepsinya tentang bagaimana penilaian orang lain terhadap tingkat prestasi yang sesungguhnya. Makin tinggi prestasi seseorang, maka makin besar pula rasa kompetensi yang dimi-likinya dan makin besar pula mereka menyukai tantangan, penuh rasa ingin tahu dan melibatkan diri dalam menguasai suatu ketrampilan.

b. Afek dalam kegiatan belajar di sekolah. Terdapat tiga afek yaitu yang berkaitan dengan mata pelajaran, dengan guru dan sekolah. Jika siswa merasa mampu dalam suatu mata pelajaran tertentu, maka ia akan menyenangi pelajaran itu. Umumnya, siswa akan terdorong bekerja lebih tekun pada mata pelajaran yang diajarkan oleh guru yang mereka senangi. Afek terhadap sekolah diperoleh dari adanya perasaan siswa memiliki kecakapan yang tinggi dalam sebagian besar tugas sekolah, menerima pengakuan yang besar bagi kegiatan belajar dan mem-punyai hubungan yang baik dengan guru maupun teman sebayanya. Sedangkan jika seorang siswa kurang berminat terhadap pelajaran tersebut, biasanya cenderung malas dan berusaha menghindarinya.

c. Persepsi tentang kontrol. Siswa yang memiliki persepsi kontrol internal memiliki harapan yang tinggi untuk berhasil dan terdorong untuk bekerja keras. Mereka menyadari bahwa keberhasilan dan kegagalan amat bergantung pada usaha mereka sendiri.

\section{FAKTOR-FAKTOR YANG MEMPENGARUHI MOTIVASI BELAJAR}

Motivasi dipengaruhi oleh banyak faktor baik yang berasal dari dalam maupun dari luar seorang siswa. Motivasi belajar dapat timbul karena adanya beberapa macam faktor yang mempengaruhinya, yaitu : 
a. Motivasi Intrinsik, yakni faktor yang berasal dari dalam diri siswa berupa aspek fisiologis (jasmaniah) dan aspek psikologis (rohaniah).

1) Aspek Fisiologis

Aspek fisiologis meliputi kondisi tubuh manusia seperti organ-organ tubuh dan sendi-sendinya. Kondisi tubuh dapat mempengaruhi semangat dan intensitas siswa dalam mengikuti pelajaran. Kondisi tubuh yang lemah dapat menurunkan kualitas ranah kognitif sehingga materi yang dipelajari menjadi sulit terserap oleh otak kita. Untuk mengatasi masalah tersebut, seorang guru perlu mengambil langkah yang bijak agar mampu mempertahankan self esteem dan self confidence siswa tersebut. Penurunan self esteem dan self confidence (rasa percaya diri) seorang siswa akan menimbulkan frustasi yang pada gilirannya cepat atau lambat siswa tersebut akan menjadi under achiever atau mungkin gagal, meskipun kapasitas kognitif mereka normal atau lebih tinggi daripada teman-temannya.

2) Aspek Psikologis

Aspek psikologis dapat mempengaruhi kuantitas dan kualitas perolehan pembelajaran seorang siswa. Namun diantara faktor-faktor psikologis siswa pada umumnya di pandang lebih esensial adalah:

a) Intelegensi (intelegency) siswa, umumnya diartikan sebagai kemampuan psiko-fisik untuk menyesuaikan diri dengan lingkungan dengan cara yang tepat. Walaupun tidak dipungkiri bahwa otak yang cerdas memiliki peran yang besar terhadap kesuksesan terhadap suatu pelajaran.

b) Sikap (attitude) siswa. Sikap adalah gejala internal yang berdimensi afektif berupa kecenderungan untuk mereaksi atau merespon dengan cara yang relatif tetap terhadap objek orang. Sikap positif terhadap mata pelajaran, akan membantu siswa lebih mudah memahami pelajaran tersebut, namun sebaliknya jika sikap negatif lebih dominan, maka secara tidak langsung suatu pelajaran akan lebih sulit untuk diterima.

c) Bakat (aptitude) siswa, adalah kemampuan potensialyang dimiliki seseorang untuk mencapai keberhasilan pada masayang akan datang. Bakat hampir mirip dengan intelegensi, karena anak yang memiliki tingkat intelegensi yang tinggi biasanya memiliki bakat yang tinggi juga. Namun dalam 
perkembangannya anak yang berbakat tidak tergantung kepada pendidikan atau pelatihan, namun lebih pada naluriah yang tersalurkan.

d) Minat (interest) siswa adalah keinginan, kecenderungan atau kegairahan yang tinggi/besar terhadap sesuatu. Minat dapat mempengaruhi kualitas pencapaian hasil belajar siswa jika dibangkitkan atau dirangsang secara kontinu.

e) Motivasi adalah keadaan internal yang mendorong melakukan sesuatu. Apabila seorang siswa bangkitkan motivasi baik dari dalam ataupun dari luar, maka akan memunculkan dorongan yang kuat terhadap keinginan untuk belajar secara maksimal.

b. Motivasi ekstrinsik adalah adanya penghargaan, lingkungan belajar yang kondusif dan kegiatan belajar yang menarik. Faktor ini secara garis besar dibagi menjadi faktor lingkungan sosial dan faktor lingkungan non sosial.

1) Lingkungan sosial. Lingkungan sosial seperti guru, staf administrasi dan temanteman sekelas dapat mempengaruhi dapat mempengaruhi semangat belajar seorang siswa. Seorang guru yang selalu menunjukan sikap yang simpatik, akan mendorong siswa untuk belajar lebih semangat. Selain itu orang tua dan masyarakat juga memiliki pengaruh yang besar. Orang tua yang selalu membimbing dengan penuh kesabaran akan memberikan motivasi terhadap kesuksesan belajar anak.

2) Lingkungan non sosial. Lingkungan non sosial meliputi gedung sekolah, jarak sekolah, rumah tempat tinggal, keadaan cuaca dan waktu akan memberikan pengaruh terhadap motivasi belajar siswa. Jika kondisi tersebut sesuai harapan akan motivasi belajar siswa akan tinggi, namun jika kondisi lingkungan non sosial tidak mendukung maka belajar siswa akan lemah.

Dari Penjelasan mengenai motivasi belajar siswa dapat dijadikan acuan untuk merumuskan indicator terhadap instrumen motivasi belajar siswa, yaitu: 
Tabel 1.

Indikator Motivasi Belajar

\begin{tabular}{|c|c|}
\hline Indikator & Intrumen \\
\hline 1. Dorongan & $\begin{array}{l}\text { a. Siswa memiliki cita-cita } \\
\text { b. Orang tua selalu memberikan motivasi untuk belajar }\end{array}$ \\
\hline $\begin{array}{l}\text { 2. Kegiatan } \\
\text { Belajar }\end{array}$ & $\begin{array}{l}\text { a. Senang mengikuti pelajaran di kelas } \\
\text { b. Bertanya apabila ada materi yang belum dipahami } \\
\text { c. Memahami pelajaran dengan baik } \\
\text { d. Mengutamakan mengerjakan tugas }\end{array}$ \\
\hline $\begin{array}{ll}\text { 3. } & \text { Unsur } \\
& \text { Pendukung }\end{array}$ & $\begin{array}{l}\text { a. Guru mengajar dengan menyenangkan } \\
\text { b. Suasana lingkungan mendukung } \\
\text { c. Membantu teman yang Mengalami kesulitan dalam } \\
\text { belajar }\end{array}$ \\
\hline $\begin{array}{l}\text { 4. Arah dan } \\
\text { Tujuan }\end{array}$ & $\begin{array}{l}\text { a. Menjadi siswa yang disiplin } \\
\text { b. Mendapatkan nilai yang memuaskan } \\
\text { c. Ikut perlombaan sehingga juara }\end{array}$ \\
\hline $\begin{array}{l}\text { 5. Perubahan } \\
\text { Tingkah } \\
\text { Laku }\end{array}$ & $\begin{array}{l}\text { a. Berpikir tenang apabila mendapat-kan masalah } \\
\text { b. Senang mendapatkan saran dan kritik dari orang lain } \\
\text { c. Belajar lebih tekun apabila menda-patkan nilai yang } \\
\text { belum memuaskan }\end{array}$ \\
\hline
\end{tabular}

\section{METODE PENELITIAN}

Jenis penelitian yang dilakukan oleh penulis adalah penelitian lapangan (field research), dengan menggunakan kualitatif deskriptif sebagai jenis penelitian utamanya. Penelitian kualitatif merupakan penelitian yang bermaksud untuk memahami fenomena tentang apa yang dialami oleh subyek penelitian misalnya perilaku, persepsi, motivasi, tindakan, dan lain-lain, secara holistik, dan dengan cara deskripsi dalam bentuk katakata dan bahasa, pada suatu konteks khusus yang alamiah dan dengan memanfaatkan berbagai metode alamiah.

Tempat penelitian adalah SMA Negeri 1 Godean Kabupaten Sleman, sedangkan penelitian ini berlangsung pada bulan April-Juni 2018. Sampel dalam penelitian ini berjumlah 36 siswa kelas $\mathrm{X}$ dan seorang Guru Bimbingan Konseling. Teknik pengumpulan data dalam penelitian ini menggunakan angket, wawancara, observasi dan dokumentasi. Sedangkan analisis data menggunakan reduksi, display dan verifikasi dengan analisis kualitatif (persentase). Perhitungan hasil angket dan observasi dengan menggunakan skala Likert, artinya setiap variabel yang akan diukur dijabarkan menjadi indikator variabel. Indikator tersebut dijadikan sebagai titik tolak untuk menyusun item- 
item instrumen yang berupa pertanyaan. Jawaban setiap item instrumen dengan skala Likert mempunyai gradasi empat tingkatan untuk masing-masing jawaban diberi skor SS $($ Sangat Setuju $)=4$, Setuju $=3$, KS $($ Kurang Setuju $)=2$ dan TS $($ Tidak Setuju $)=1$.

Cara menghitung skor observasi dan angket terhadap kegiatan siswa yang dilakukan baik di rumah maupun sekolah adalah sebagai berikut:

$$
P=\frac{f}{N} \times 100 \%
$$

Keterangan $\quad P \quad: \quad$ Persentase

F : Jumlah Skor

$\mathrm{N}$ : $\quad$ Skor maksimal

Kemudian dari nilai persentase yang ada dikatergorikan dengan rentang sebagai berikut:

$$
\begin{array}{rll}
>85,56 & : & \text { Sangat Baik/ Sangat Tinggi } \\
70,56-85,55 & : & \text { Baik/Tinggi } \\
60,56-70,55 & : & \text { Cukup Baik/Cukup Tinggi = Sedang } \\
<60,55: & \text { Tidak Baik/Tidak Tinggi }
\end{array}
$$

\section{HASIL DAN ANALISIS PENELITIAN}

\section{Kecerdasan Spiritual Siswa SMA Negeri 1 Godean}

Kecerdasan spiritual adalah suatu kecerdasan (kemampuan) yang terdapat dalam diri seseorang yang dapat ditunjukkan melalui perilaku-perilaku keruhaniahan atau keagamaan.Kecerdasan spiritual merupakan kemampuan tertinggi yang dimiliki oleh suatu individu yang dapat memfungsikan kecerdasan intelektual dan emosional secara efektif melalui rasa cinta dan kasih sayang kepada sesamanya karena kesalehannnya terhadap Allah. Potensi kecerdasan spiritual manusia akan terus cemerlang selama manusia mau mengasahnya, sebab potensi yang secara hakiki ditiupkan ke dalam tubuh manusia ruh kebenaran, yang selalu mengajak kepada kebenaran.

Kecerdasan spiritual SMA Negeri 1 Godean secara garis besar tergolong baik. Kecerdasan spiritual akan menumbuhkan kesadaran setiap untuk melakukan aktivitasaktivitas yang positif dan bermakna. Danah Zohar dan Ian Marsall mengemukakan bahwa orang yang memiliki kcerdasan spiritual yang tinggi cenderung berperilaku dan 
bersikap secara arif dan bijak. Hal senada sesuai yang disampaikan Jalaluddin, bahwa kecerdasan spiritual akan mengahantarkan manusia kepada transendensikasi diri. Dimana seseorang yang memiliki kecerdasan spiritual akan tertindak secara arif dan bijaksana. Perilaku inilah yang banyak dilakukan oleh siswa di SMA Negeri 1 Godean secara etika sopan santun, rata-rata siswa sangat baik dan sopan. Hal ini secara dapat di lihat seperti tabel di bawah ini.

Tabel 2.

Hasil Kecerdasan Spiritual

\begin{tabular}{|c|c|c|c|c|}
\hline No & Indikator & Skor & Jumlah & Rata-rata \\
\hline 1 & Keyakinan adanya Allah & 137 & 95.14 & \multirow{11}{*}{90.66} \\
\hline 2 & $\begin{array}{l}\text { Melaksanakan shalat sebagai } \\
\text { pengabdian }\end{array}$ & 114 & 79.17 & \\
\hline 3 & Merasa diawasi Allah & 140 & 97.22 & \\
\hline 4 & Rajin Berdoa & 134 & 93.06 & \\
\hline 5 & Kebiasaan membaca al-Qur'an & 130 & 90.28 & \\
\hline 6 & Mendapatkan pertolongan Allah & 133 & 92.36 & \\
\hline 7 & Bergaul sesuai etika & 124 & 86.11 & \\
\hline 8 & Toleransi antarumat beragama & 132 & 91.67 & \\
\hline 9 & Mudah memaafkan kesalahan & 123 & 85.42 & \\
\hline 10 & Suka membantu orang lain & 129 & 89.58 & \\
\hline 11 & Memperlakukan orang dengan baik & 140 & 97.22 & \\
\hline
\end{tabular}

Berdasarkan tabel di atas, dapat dilihat bahwa rata-rata tingkat kecerdasan spiritual siswa SMA Negeri 1 Godean adalah sangat baik (90,66\%). Untuk keyakinan adanya Allah, Merasa diawasi oleh Allah, rajin berdoa dan dzikir, kebiasaan membaca al-Qur'an, merasa selalau mendapat pertolongan dari Allah, bergaul sesuai etika agama, toleransi beragama, suka menolong orang lain serta berbuat baik kepada orang yang menyakini kita siswa SMA Negeri 1 Godean termasuk kategori sangat baik; sedangkan mudah memaafkan kesalahan orang lain termasuk kategori baik. Hal ini mengingat siswa SMA tergolong usia remaja, yang secara emosi masih memiliki ego yang besar, 
namun secara psikologi kategori 'baik' secara dalam berinteraksi dengan orang lain dikatakan sangatlah wajar. Hal ini didukung dengan hasil wawancara dengan guru BK SMA Negeri 1 Godean.

Untuk tingkat kenakalan dan pergaulan anak di SMA Godean masih sangat wajar. Mengapa saya katakana wajar, anak-anak di sini secara afeksi dan psikomotorik sangat mudah dikendalikan. Mereka lebih banyak sibuk dengan kegiatan-kegiatan sekolah seperti keagamaan, olahraga dan organisasi lainnya. Mereka jarang berkumpul-kumpul yang sifatnya hura-hura atau kenakalan remaja.

\section{Motivasi Belajar Siswa di SMA Negeri 1 Godean}

Motivasi belajar adalah hasil yang dicapai dalam sebuah aktivitas belajar oleh siswa, sehingga prestasi bisa dikatakan sebagai kegiatan yang dapat diukur secara langsung dengan tes. Motivasi belajar lebih mengarah kepada perubahan tingkah laku yang berwujud kepada perubahan pengetahuan, ketrampilan, sikap dan nilai sebagai hasil proses belajar. Dengan begitu motivasi belajar bagi siswa sangat penting, karena motivasi belajar merupakan salah satu gambaran tingkat keberhasilan dari kegiatan selama mengikuti pelajaran.

Motivasi belajar merupakan perubahan pola tingkah laku dan sikap seorang siswa, hal ini senada sesuai dengan penyataan M. Surya. Artinya hasil yang diperoleh seorang siswa tidak hanya pada sisi kognitif saja, melainkan juga pada sikap mereka. Perubahan tersebut tentu diharapkan mampu membekali siswa menjalani kehidupan. Gambaran hasil belajar siswa SMA Negeri 1 Godean dapat dilihat dalam tabel berikut ini:

Tabel 3.

Hasil Motivasi Belajar Siswa

\begin{tabular}{|c|l|c|c|c|}
\hline No & \multicolumn{1}{|c|}{ Indikator } & Skor & Jumlah & Rata-rata \\
\cline { 1 - 3 } 1 & Antusias mengikuti pelajaran & 130 & 90.28 & \\
\cline { 1 - 3 } 2 & Menegur teman yang gaduh & 97 & 67.36 & \multirow{2}{*}{79.44} \\
\cline { 1 - 3 } 3 & Bertanya kepada guru & 124 & 86.11 & \\
\cline { 1 - 3 } 5 & Mengerjakan tugas & 133 & 92.36 & \\
\cline { 1 - 3 } & Mengikuti perlombaan & 88 & 61.11 & \\
\end{tabular}


Berdasarkan tabel di atas, dapat dijelaskan bahwa rata-rata motivasi belajar siswa SMA Negeri 1 Godean termasuk kategori Baik (79,44\%). Untuk aktivitas mengerjakan tugas dan kemampuan berdiskusi terhadap materi pelajaran yang belum dipahami termasuk kategori 'sangat baik', sedangkan untuk sikap antusiasme dalam mengikuti pelajaran, menegur teman yang gaduh di dalam kelas dan aktivitas perlombaan termasuk kategori 'baik'.

Secara akademik, kelas X siswa SMA Negeri 1 Godean bisa dikatakan belum maksimal, dikarenakan kelas X merupakan masa peralihan antara tingkat SMP ke SMA. Sehingga masih banyak aktivitas-aktivitas siswa di masa SMP yang masih terbawa hingga jenjang SMA. Hal ini diperkuat dengan hasil wawancara dengan Guru BK kelas $\mathrm{X}$ yaitu:

"Untuk motivasi kelas X memang belum kelihatan perkembangannya. Hal ini biasanya karena rata-rata anak kelas $\mathrm{X}$ masih melakukan adaptasi dengan kondisi sekolah. Mereka masih malu-malu dalam berbanyak hal, seperti masih canggung ketemu kakak kelas, takut bertanya dan untuk kegiatan perlombaan belum banyak dilibatkan. Kegiatan ekstrakulikuler yang padat ditambah dengan kegiatan tambahan pelajaran lainnya."

\section{Dampak Kecerdasan Spiritual terhadap Motivasi Belajar Siswa}

Dalam mewujudkan prestasi hasil belajar, seorang guru perlu memahami seberapa kekuatan kecerdasan spiritual siswa. Dimana kecerdasan spiritual merupakan kemampuan untuk member makna ibadah terhadap setiap perilaku dan kegiatan, karena ia akan memberikan kemampuan kepada manusia untuk membedakan kepada manusia yang baik dengan yang buruk, member manusia rasa bermoral dan memberi manusia kemampuan untuk menyesuaikan dirinya dengan aturan-aturan yang baru.

Kecerdasan spiritual dan motivasi belajar diharapkan berbanding lurus, artinya siswa yang memiliki kecerdasan spiritual yang baik diharapkan memiliki motivasi belajar yang baik pula. Karena menurut Toto Tasmara, pada prinsipnya sejak manusia lahir sudah memiliki kecerdasan ruhaniah. Siswa yang tingkat spiritualnya baik, akan lebih mudah untuk dikembangkan sisi motivasi belajarnya. Menurut Abdul Mujib bahwa kecerdasan spiritual akan memberdayakan dan mengarahkan seluruh potensi qalb (fu'ad, shadr dan hawa) sehingga akan menunjukkan tanggung jawab dengan berorientasi kepada kebijakan dan semangat berbuat amal kebaikan tanpa banyak mengeluh, putus asa dan selalu berusaha mencapai tujuan yang diridhoi oleh pencipta- 
Nya. Gambaran kecerdasan spiritual terhadap motivasi belajar siswa di SMA Negeri 1

Godean dapat dilihat dalam tabel berikut:

Tabel 4.

Gambaran Kecerdasan Spritual Terhadap Motivasi Belajar

\begin{tabular}{|c|l|c|c|c|}
\hline No & \multicolumn{1}{|c|}{ Indikator } & Skor & Jumlah & Rata-rata \\
\hline 1 & Selalu Ikhtiar & 137 & 95.14 & \\
\cline { 1 - 4 } 2 & Optimistis & 127 & 88.19 & \multirow{2}{*}{92.01} \\
\cline { 1 - 3 } 3 & Tawakal & 129 & 89.58 & \\
\cline { 1 - 3 } 4 & Syukur & 137 & 95.14 & \\
\hline
\end{tabular}

Berdasarkan tabel di atas tingkat keterkaitan antara kecerdasan spiritual terhadap motivasi belajar siswa sanga baik, sehingga bisa digambarkan bahwa di SMA Negeri 1 Godean penggambaran pengaruh kecerdasan spiritual dan motivasi belajar siswa sangat besar.

\section{DAFTAR PUSTAKA}

Afifudin, Psikologi Pendidikan Anak Usia Sekolah Dasar, (Solo: Penerbit Harapan Massa, 1986).

Alisuf Sabri, Psikologi Pendidikan, (Jakarta: Pedoman Ilmu Jaya, 2002).

Danah Zohar dan Ian Marshall, SQ; Kecerdasan Spiritual, (Bandung : Mizan, 2007).

Elida Priyitno, Motivasi dalam Belajar, (Jakarta: P2LPTK, 1989).

Endang Sri Astuti dan Resminingsih, Bahan Dasar Untuk Pelayanan Konseling pada Satuan Pendidikan Menengah Jilid I, (Jakarta : PT Grasindo, 2010).

Hamzah B. Uno, Teori Motivasi dan Pengukurannya, (Jakarta: Bumi Aksara, 2011).

Jalaluddin, Psikologi Agama, (Jakarta: Rajawali Press, 2012).

Jejen, Kecerdasan Akal menurut Hadits, (Jakarta: Kordinat, 2 oktober 2005).

Muhibbin Syah, Psikologi Pendidikan dengan Pendekatan Baru, (Bandung: Remaja Rosdakarya, 2002).

Mulyadi Psikologi Pendidikan, (Malang: Biro Ilmiah IAIN Sunan Ampel, 1991). 
Reni-Hawadi Akbar, Psikologi Perkembangan Anak: Mengenal Sifat, Bakat, dan Kemampuan Anak, (Jakarta: Grasindo, 2001).

Samidjo Mardiani, Bimbingan Belajar, (Bandung: Armico, 1985).

Sardiman AM, Interaksi dan Motivasi Belajar Mengajar, (Jakarta: Rajawali Press, 2016).

Taufik Pasiak, Revolusi IQ / EQ /SQ Antara Neurosains dan Al-Quran, (Bandung: Mizan Pustaka, 2002).

Toto Tasmara, Kecerdasan Ruhaniyah Transcendental Intellegence, (Jakarta: Gema Insani Press, 2011). 